\title{
Emerging viral diseases of fish and shrimp
}

\author{
Peter J. WALKER ${ }^{1 *}$, James R. WINTON ${ }^{2}$ \\ ${ }^{1}$ CSIRO Livestock Industries, Australian Animal Health Laboratory (AAHL), 5 Portarlington Road, \\ Geelong, Victoria, Australia \\ ${ }^{2}$ USGS Western Fisheries Research Center, 6505 NE 65th Street, Seattle, Washington, USA
}

(Received 7 December 2009; accepted 19 April 2010)

\begin{abstract}
The rise of aquaculture has been one of the most profound changes in global food production of the past 100 years. Driven by population growth, rising demand for seafood and a levelling of production from capture fisheries, the practice of farming aquatic animals has expanded rapidly to become a major global industry. Aquaculture is now integral to the economies of many countries. It has provided employment and been a major driver of socio-economic development in poor rural and coastal communities, particularly in Asia, and has relieved pressure on the sustainability of the natural harvest from our rivers, lakes and oceans. However, the rapid growth of aquaculture has also been the source of anthropogenic change on a massive scale. Aquatic animals have been displaced from their natural environment, cultured in high density, exposed to environmental stress, provided artificial or unnatural feeds, and a prolific global trade has developed in both live aquatic animals and their products. At the same time, over-exploitation of fisheries and anthropogenic stress on aquatic ecosystems has placed pressure on wild fish populations. Not surprisingly, the consequence has been the emergence and spread of an increasing array of new diseases. This review examines the rise and characteristics of aquaculture, the major viral pathogens of fish and shrimp and their impacts, and the particular characteristics of disease emergence in an aquatic, rather than terrestrial, context. It also considers the potential for future disease emergence in aquatic animals as aquaculture continues to expand and faces the challenges presented by climate change.
\end{abstract}

disease emergence / shrimp / fish / virus

\section{Table of contents}

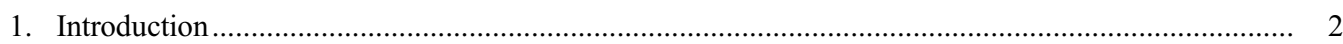

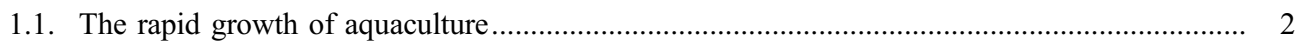

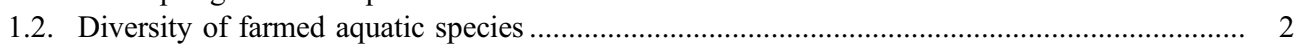

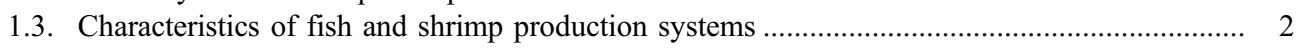

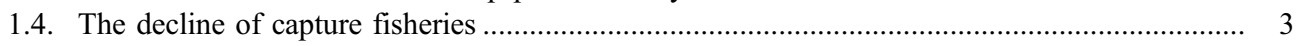

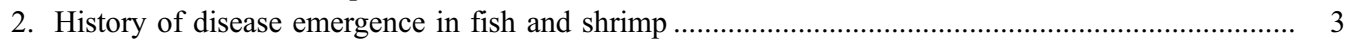

2.1. Problems associated with emerging diseases .................................................................. 3

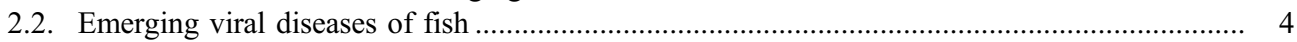

2.3. Emerging viral diseases of shrimp …................................................................................. 8

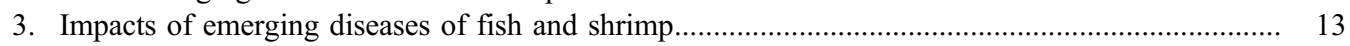

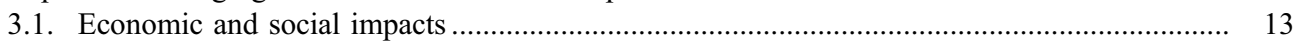

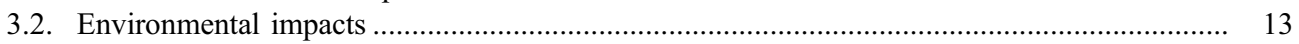

\footnotetext{
* Corresponding author: Peter.Walker@csiro.au

This is an Open Access article distributed under the terms of the Creative Commons Attribution-Noncommercial License (http://creativecommons.org/licenses/by-nc/3.0/), which permits unrestricted use, distribution, and reproduction in any noncommercial medium, provided the original work is properly cited.
} 
4. Factors contributing to disease emergence in aquatic animals ..................................................... 14

4.1. Activities related to the global expansion of aquaculture ................................................... 15

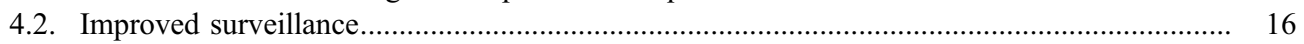

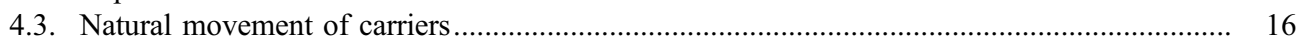

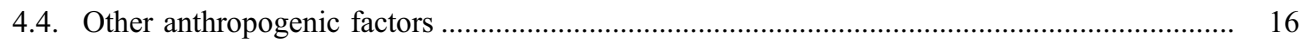

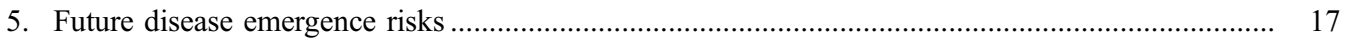

\section{INTRODUCTION}

\subsection{The rapid growth of aquaculture}

The farming of fish and other aquatic animals is an ancient practice that is believed to date back at least 4000 years to pre-feudal China. There are also references to fish ponds in The Old Testament and in Egyptian hieroglyphics of the Middle Kingdom (2050-1652 BC). Fish farms were common in Europe in Roman times and a recent study of land forms in the Bolivian Amazon has revealed a complex array of fish weirs that pre-date the Hispanic era $[30,49]$. However, despite its ancient origins, aquaculture remained largely a low-level, subsistence farming activity until the mid-20th century when experimental husbandry practices for salmon, trout and an array of tropical fish and shrimp species were developed and adopted. Aquaculture is now a major global industry with total annual production exceeding 50 million tonnes and estimated value of almost US\$ 80 billion [32]. With an average annual growth of $6.9 \%$ from $1970-2007$, it has been the fastest growing animal food-producing sector and will soon overtake capture fisheries as the major source of seafood [31].

\subsection{Diversity of farmed aquatic species}

In contrast to other animal production sectors, aquaculture is highly dynamic and characterised by enormous diversity in both the range of farmed species and in the nature of production systems. Over 350 different species of aquatic animals are farmed, including 34 finfish (piscean), 8 crustacean and 12 molluscan species each for which annual production exceeds 100000 tonnes [32]. Aquatic animals are farmed in freshwater, brackishwater and marine environments, and in production systems that include caged enclosures, artificial lakes, earthen ponds, racks, rafts, tanks and raceways. Farming can be a small-scale traditional activity with little human intervention, through to sophisticated industrial operations in which animals are bred and managed for optimal performance and productivity. The diversity of aquaculture species and farming systems also extends geographically from tropical to subarctic climes and from inland lakes and rivers to estuaries and open offshore waters.

Aquaculture production is heavily dominated by China and other developing countries in the Asia-Pacific region which accounts for $89 \%$ by volume of global production and $77 \%$ by value [31]. The major farmed species are carp, oysters and shrimp of which 98\%, $95 \%$ and $88 \%$ of production, respectively, originates in Asia. By contrast, Atlantic salmon production is dominated by Norway, Chile, the United Kingdom and Canada which together account for $88 \%$ by volume and $94 \%$ by value [32]. Capture fisheries and aquaculture, directly or indirectly, play an essential role in the livelihoods of millions of people, particularly in developing countries. In 2006, an estimated 47.5 million people were primarily or occasionally engaged in primary production of aquatic animals [31].

\subsection{Characteristics of fish and shrimp production systems}

Although a significant component of the small-scale aquaculture sector continues to rely on traditional methods of natural recruitment of seed into ponds, modern fish and shrimp production systems more typically involve 
a hatchery/nursery phase in which broodstock are spawned or stripped for the collection and hatching of eggs, and in which larvae are nursed through to post-larvae or juvenile stages (i.e., fry, smolt, fingerling) for delivery to farms. Broodstock may be captured from wild fisheries or produced in captivity from mature farmed stock or from closed-cycle breeding and genetic improvement programs. The use of wild broodstock that may be healthy carriers of viral pathogens is arguably the most significant biosecurity risk in aquaculture. Farming systems employed for grow-out may be extensive or intensive. Extensive farming employs fish or shrimp trapped at low density in natural or man-made enclosures utilising natural sources of feed with minimal human intervention. Intensive systems employ medium-to-high stocking densities in cages or ponds and artificial or supplemental feeds. Intensive pond culture usually requires aeration and controlled water exchange to maintain water quality. Super-intensive recirculating aquaculture systems (RAS) are also employed for some species. On-farm biosecurity measures to exclude pathogens and minimise health risks are more commonly employed in intensive and superintensive systems.

\subsection{The decline of capture fisheries}

Whilst aquaculture has been on a steady path of expansion, capture fishery production has levelled since 1990 and many of the world's major fisheries have been driven into a state of decline by unsustainable fishing practices and environmental pressures. It has been estimated that 11 of the 15 major fishing areas and $80 \%$ of marine fishery resources are currently overexploited or at their maximum sustainable limit [31]. Much of the pressure on wild stocks is due to commercial fishing but the increasing popularity of recreational angling has led to a growing awareness of the need for regulation to ensure marine and inland fishery sustainability. Disease emergence is also a concern in wild fisheries due to environmental pressures, the direct impact of human activities and the risk of pathogen spread from aquaculture [102].

\section{HISTORY OF DISEASE EMERGENCE IN FISH AND SHRIMP}

Whilst various forms of disease have been reported among aquatic animals for centuries, most were either non-infectious (e.g., tumours), or caused by common endemic pathogens (mainly parasites and bacteria), and thus already known among observers and those engaged in traditional aquaculture. However, during the past century, the rise of novel forms of intensive aquaculture, increased global movement of aquatic animals and their products, and various sources of anthropogenic stress to aquatic ecosystems have led to the emergence of many new diseases in fish and shrimp. In this review, we consider these emerging diseases as: (i) new or previously unknown diseases; (ii) known diseases appearing for first time in a new species (expanding host range); (iii) known diseases appearing for the first time in a new location (expanding geographic range); and (iv) known diseases with a new presentation (different signs) or higher virulence due to changes in the causative agent.

\subsection{Problems associated with emerging diseases}

Emerging disease epizootics frequently cause substantial, often explosive, losses among populations of fish and shrimp, resulting in large economic losses in commercial aquaculture and threats to valuable stocks of wild aquatic animals. However, the extent of disease spread and impacts are often exacerbated by other problems that are typically encountered including: (i) delay in developing tools for the confirmatory diagnosis of disease or identification of the causative agent that allows infected animals to go undetected; (ii) poor knowledge of the current or potential host range; (iii) inadequate knowledge of the present geographic range; (iv) no understanding of critical epidemiological factors (replication cycle, mode of transmission, reservoirs, vectors, stability); and (v) poor understanding of differences among strains and/or relationships to established pathogens. Interventions to prevent pathogen spread are also often limited by poor capacity in some developing countries for implementation of effective quarantine and/or biosecurity measures and the illegal or poorly 
regulated international trans-boundary movement of live aquatic animals [128, 164].

\subsection{Emerging viral diseases of fish}

Important emerging viral pathogens of fish are found among many families of vertebrate viruses that are well-known to include pathogens of humans or domestic livestock. However, there are significant differences between the ecology of viral diseases of fish and those of humans or other terrestrial vertebrates. The most significant amongst these differences are that: (i) few fish viruses are known to be vectored by arthropods; (ii) water is a stabilizing medium, but currents are less effective for long range virus transmission than are aerosols; (iii) wild reservoir species are often at very low densities (except for schooling and aggregate spawning stocks); (iv) fish are poikilotherms and temperature has an exceptionally critical role in modulating the disease process by affecting both the replication rate of the virus as well as the host immune response and other physiological factors involved in resistance; (v) few fish viruses are transmitted sexually between adults, although high levels of some viruses are present in spawning fluids and a few viruses are transmitted vertically from adult to progeny, either intra-ovum or on the egg surface. However, as occurs for avian diseases, migratory fish can serve as carriers for longrange dispersal of viral pathogens.

The global expansion of finfish aquaculture and accompanying improvements in fish health surveillance has led to the discovery of several viruses that are new to science. Many of these are endemic among native populations and opportunistically spill-over to infect fish in aquaculture facilities. Other well-characterized fish viruses (e.g., channel catfish virus, Onchorhynchus masou virus) can also cause significant losses in aquaculture but do not seem to be increasing significantly in host or geographic range. In the following sections, we consider the major emerging fish virus diseases that cause significant losses in aquaculture and are expanding in host or geographic range (Tab. I). Because of the risk of spread through commercial trade in finfish, many of the dis- eases are listed as notifiable by the World Organization for Animal Health (OIE).

\subsubsection{Infectious haematopoietic necrosis}

Infectious haematopoietic necrosis is one of three rhabdovirus diseases of fish that are listed as notifiable by the OIE. Originally endemic in the western portion of North America among native species of anadromous salmon, infectious haematopoietic necrosis virus (IHNV) emerged in the 1970s to become an important pathogen of farmed rainbow trout (Oncorhynchus mykiss) in the USA [11, 156]. Subsequently, the virus was spread by the movement of contaminated eggs to several countries of Western Europe and East Asia, where it emerged to cause severe losses in farmed rainbow trout, an introduced species. Similar to other members of the genus Novirhabdovirus in the family Rhabdoviridae, IHNV contains a negative-sense, single-stranded RNA genome, approximately 11000 nucleotides in length and encoding six proteins, packaged within an enveloped, bullet-shaped virion [67]. Isolates of IHNV from North America show a strong phylogeographic signature with relatively low genetic diversity among isolates from sockeye salmon (Oncorhynchus nerka) inhabiting the historic geographic range of the virus [66]. However, isolates from trout in Europe, Japan or Korea, where the virus is emerging, show evidence of independent evolutionary histories following their initial introduction $[29,64,106]$. The emergence of IHNV in rainbow trout aquaculture is accompanied by genetic changes that appear to be related to a shift in host specificity and virulence [112].

\subsubsection{Viral haemorrhagic septicaemia}

Viral haemorrhagic septicaemia (VHS) is another emerging disease caused by a fish rhabdovirus. Similar to IHNV in morphology and genome organization, viral haemorrhagic septicaemia virus (VHSV) is also a member of the genus Novirhabdovirus [67]. The virus was initially isolated and characterized in Europe where it had become an important cause of loss among rainbow trout reared in aquaculture 
Table I. Emerging viral pathogens of finfish.

\begin{tabular}{|c|c|c|c|c|c|}
\hline Virus & Abbreviation & Genome & Taxonomic classification $^{1}$ & $\begin{array}{l}\text { Known geographic } \\
\text { distribution }\end{array}$ & OIE listed $^{2}$ \\
\hline \multicolumn{6}{|l|}{$D N A$ viruses } \\
\hline $\begin{array}{l}\text { Epizootic haematopoietic necrosis virus } \\
\text { and other ranaviruses }\end{array}$ & EHNV & dsDNA & Iridoviridae, Ranavirus & $\begin{array}{l}\text { Australia, Europe, Asia, } \\
\text { North America, Africa }\end{array}$ & Yes \\
\hline Red sea bream iridovirus & RSIV & dsDNA & Iridoviridae, Megalocytivirus & Asia & Yes \\
\hline Koi herpesvirus & KHV & dsDNA & Alloherpesviridae, Cyprinivirus & $\begin{array}{l}\text { Asia, Europe, North } \\
\text { America, Israel, Africa }\end{array}$ & Yes \\
\hline \multicolumn{6}{|l|}{ RNA Viruses } \\
\hline Infectious haematopoietic necrosis virus & IHNV & $(-)$ ssRNA & $\begin{array}{c}\text { Mononegavirales, Rhabdoviridae, } \\
\text { Novirhabdovirus }\end{array}$ & $\begin{array}{c}\text { Europe, North America, } \\
\text { Asia }\end{array}$ & Yes \\
\hline Viral haemorrhagic septicaemia virus & VHSV & $(-)$ ssRNA & $\begin{array}{c}\text { Mononegavirales, Rhabdoviridae, } \\
\text { Novirhabdovirus }\end{array}$ & $\begin{array}{c}\text { Europe, North America, } \\
\text { Asia }\end{array}$ & Yes \\
\hline Spring viraemia of carp virus & SVCV & $(-)$ ssRNA & $\begin{array}{c}\text { Mononegavirales, Rhabdoviridae, } \\
\text { Vesiculovirus }\end{array}$ & $\begin{array}{l}\text { Europe, Asia, North and } \\
\text { South America }\end{array}$ & Yes \\
\hline Infectious salmon anaemia virus & ISAV & $(-)$ ssRNA & Orthomyxoviridae, Isavirus & $\begin{array}{c}\text { Europe, North and South } \\
\text { America }\end{array}$ & Yes \\
\hline Viral nervous necrosis virus & VNNV & $(+)$ ssRNA & Nodaviridae, Betanodavirus & $\begin{array}{c}\text { Australia, Asia, Europe, } \\
\text { North America, Africa, } \\
\text { South Pacific }\end{array}$ & No \\
\hline
\end{tabular}

${ }^{1}$ ICVT, 2009.

2 OIE, 2009. 
[123]. Prior to the 1980s, VHSV was assumed to be largely endemic among native freshwater species of fish in Western Europe where it spilled-over to the introduced, and presumably more susceptible, rainbow trout [156]. Subsequently, an increasing number of virological surveys of anadromous and marine fish in the North Pacific and North Atlantic Oceans revealed a much greater host and geographic range than previously recognized $[35,91,99$, 121], and VHSV was shown to cause significant losses in both cultured and free-ranging species of marine fish [48, 56]. The understanding that VHS appeared to be an emerging disease of marine fish as a result of both greater surveillance efforts and the development of novel forms of marine fish aquaculture was further extended when VHS emerged for the first time in the Great Lakes of North America. The explosive losses among free-ranging native species revealed how devastating the disease can be when first introduced into naive populations of freshwater fish [28, 40, 84].

\subsubsection{Spring viraemia of carp}

Spring viraemia of carp (SVC) is also caused by a fish rhabdovirus (SVCV). However, unlike IHNV and VHSV, SVCV is related to rhabdoviruses in the genus Vesiculovirus in having an enveloped, bullet-shaped virion with somewhat shorter morphology and lacking the non-virion gene characteristic of novirhabdoviruses [67]. Initially believed to be endemic among common carp (Cyprinus carpio) in Eastern and Western Europe, the disease appeared in the spring to cause large losses among farm-reared carp [2, 156]. More recently, SVCV has emerged in several regions of the world where it has been associated with very large losses in common carp and its ornamental form, the koi carp. These outbreaks have occurred in both farmed and wild fish, suggesting a recent range expansion. The emergence of SVC in North America, Asia and in portions of Europe, formerly free of the virus, appears to be a result of both improved surveillance and the global shipment of large volumes of ornamental fish, including koi carp. Genotyping of isolates of SVCV and a closely related fish rhabdovirus from Europe, pike fry rhabdovirus, from various locations have revealed the isolates form four major genetic clades [127], and that the isolates of SVCV representing the recent emergence and geographic range expansion appear to have links to the spread of the virus within China where common carp are reared in large numbers for food and koi are reared for export [92].

\subsubsection{Infectious salmon anaemia}

Infectious salmon anaemia (ISA) is an emerging disease of farmed Atlantic salmon (Salmo salar) caused by a member of the family Orthomyxoviridae. The virus (ISAV) has eight independent genome segments of negative-sense, single-stranded RNA packaged within a pleomorphic, enveloped virion, approximately $100-130 \mathrm{~nm}$ in diameter, and is the type species of the genus Isavirus. Initially identified as the causative agent of outbreaks and high rates of mortality among Atlantic salmon reared in sea cages in parts of Norway [109], ISAV subsequently emerged to cause losses in other areas of Western Europe where Atlantic salmon are farmed [95]. The virus was also confirmed to be the cause of an emerging hemorrhagic kidney disease of farmed Atlantic salmon along the Atlantic coast of Canada and the USA [82]. Isolates of ISAV form two major genotypes containing isolates from Europe and North America, respectively [62]. More recently, ISAV has caused very extensive losses in the Atlantic salmon farming industry in Chile. Genetic analysis has revealed that the Chilean isolates group with those from Norway and that the virus was likely transferred to Chile sometime around 1996 by the movement of infected eggs [63]. Although principally known as a pathogen of Atlantic salmon, ISAV has been isolated from naturally infected marine species that are apparent reservoirs for virus spill-over to susceptible Atlantic salmon in sea cages [115]. Investigation of virulence determinants of ISAV has also revealed significant differences among isolates [88]. Thus, the emergence of ISA appears to be a response to the farming of a susceptible species in an endemic area, evolution of the virus and 
some degree of transmission via the movement of fish or eggs used in aquaculture.

\subsubsection{Koi herpesvirus disease}

The disease caused by koi herpesvirus (KHV) is amongst the most dramatic examples of an emerging disease of fish. KHV is a member of the genus Cyprinivirus in the family Alloherpesviridae. Koi herpesvirus disease is relatively host-specific; although other cyprinid species have been shown to be susceptible, only common carp (C. carpio) and its ornamental subspecies, the koi carp, have been involved in the explosive losses that have been reported globally in areas where the virus has been first introduced [47]. The enveloped virion of KHV, formally classified as the species Cyprinid herpesvirus 3, has a morphology typical of herpesviruses and contains a double-stranded DNA genome of approximately $295 \mathrm{kbp}$ [5]. Molecular analysis has shown little variation among isolates, as might be expected for a virus that is being rapidly disseminated by the global movement of infected fish [37]; however, minor variation has been reported that may reflect at least two independent introductions or emergence events of KHV [68]. A significant problem is that once fish are infected, the virus persists for some period of time in a latent or carrier state without obvious clinical signs [125]. It appears that the movement of such carriers via the extensive trade in cultured ornamental fish has resulted in the rapid appearance of the disease in many regions of the world [41]. In addition, the release or stocking of ornamental fish into ponds and other natural waters has resulted in the introduction of KHV to naive wild populations, where the initial exposure can result in substantial mortality.

\subsubsection{Epizootic haematopoietic necrosis and other ranavirus diseases}

Epizootic haematopoietic necrosis is caused by a large DNA virus (EHNV) which is classified in the genus Ranavirus of the family Iridoviridae [152]. Initially discovered in Australia where it was identified as an important cause of mortality among both cultured rainbow trout and a native species, the redfin perch [71], it later became clear that EHNV was but one of a large pool of ranaviruses having a broad host and geographic range that included amphibians, fish and reptiles [53]. Isolated from sub-clinical infections as well as severely diseased fish in either aquaculture or the wild, the genetically diverse, but related, ranaviruses have been given many names in different locations [86]. Although, there is evidence of spread by the movement of infected fish, either naturally or via trade, an important driver of the emergence of ranavirus diseases in finfish aquaculture seems to be the spill-over of virus from endemic reservoirs among native fish, amphibians or reptiles [152]. In this regard, ranaviruses related to the type species, Frog Virus 3, have been shown to be an important cause of emerging disease among both cultured and wild amphibian populations and may be associated, at least in some areas, with their global decline [19]. Both the large, unregulated global trade in amphibians and the unintended movement of ranaviruses by humans, including anglers and biologists, have been postulated to be important methods of dissemination of these relatively stable viruses to new aquatic habitats [114].

\subsubsection{Red sea bream iridoviral disease and other megalocytivirus diseases}

Another group of emerging iridoviruses causes disease in marine as well as freshwater fish species [19]. Initially identified in 1990 as the cause of high rate of mortality among cultured red sea bream (Pagrus major) in southwestern Japan [54], the causative agent termed red sea bream iridovirus (RSIV) was shown to affect at least 31 species of marine fish cultured in the region $[60,89]$. Antigenic and molecular analyses revealed the causative agent of these outbreaks differed from other known fish iridoviruses [69, 103]. Soon, reports began to emerge that similar viral diseases in new hosts and other geographic areas of Asia were associated with novel iridoviruses including: infectious spleen and kidney necrosis iridovirus (ISKNV) from cultured mandarinfish (Sinaperca chuatsi) in southern China, sea bass (Lateolabrax sp.) iridovirus (SBIV) 
from Hong Kong, rock bream (Oplegnathus fasciatus) iridovirus (RBIV) from Korea and the orange-spotted grouper (Epinephelus coiodes) iridovirus (OSGIV) from China [27, 45, 83, 94]. Sequence analysis showed these and several additional, but related, viruses formed a novel group and have been assigned to the genus Megalocytivirus in the family Iridoviridae, with ISKNV as the type species [27, 46, 69, 83]. In addition to causing outbreaks associated with severe necrosis and high mortality in a wide range of cultured marine fish, these viruses have emerged to affect freshwater species such as the African lampeye (Aplocheilichthys normani) and dwarf gourami (Colisa lalia) in which they have caused additional losses [132]. Molecular epidemiological studies have shown that megalocytiviruses form at least three genetic lineages. There is evidence that some of the initial outbreaks in marine species were due to spill-over from viruses endemic among free-ranging fishes; in other cases, there are clear links to the international movement of both marine and ornamental fish $[132,150,152]$.

\subsubsection{Viral nervous necrosis and other nodavirus diseases}

Viral nervous necrosis (VNN) has emerged to become a major problem in the culture of larval and juvenile marine fish worldwide [101]. Initially described as a cause of substantial mortality among cultured barramundi (Lates calcarifer) in Australia where the disease was termed vacuolating encephalopathy and retinopathy, the condition was shown to be caused by a small, icosahedral virus that resisted cultivation in available cell lines, but appeared similar to picornaviruses [38, 100]. Around the same time, efforts to expand marine fish aquaculture in other regions of the world revealed disease conditions associated with similar viruses in larvae or juveniles from a range of species including turbot (Scophthalmus maximus) in Norway [8], sea bass (Dicentrarchus labrax) in Martinique and the French Mediterranean [12], and parrotfish (Oplegnathus fasciatus) and redspotted grouper (Epinephelus akaara) in Japan $[97,163]$. In Japan, the disease was termed ner- vous necrosis and the virus infecting larval striped jack (Pseudocaranx dentex), now assigned as the species Striped jack nervous necrosis virus (SJNNV), was shown to be a putative member of the family Nodaviridae [98]. Following isolation in cell culture [34], sequence analysis of the coat protein gene supported the creation of a novel genus, Betanodavirus, within the family Nodaviridae to include isolates of fish nodaviruses from various hosts and geographic locations [104, 105]. These and other phylogenetic analyses [23, $122,139]$ revealed that genetic lineages of the betanodaviruses show low host specificity and generally correspond to geographic location, indicating they emerged due to spill-over from reservoirs that include a broad range of wild marine fish, although some isolates revealed links to commercial movement.

\subsection{Emerging viral diseases of shrimp}

Shrimp is the largest single seafood commodity by value, accounting for $17 \%$ of all internationally traded fishery products. Approximately $75 \%$ of production is from aquaculture which is now almost entirely dominated by two species - the black tiger shrimp (Penaeus monodon) and the white Pacific shrimp (Penaeus vannamei) that represent the two most important invertebrate food animals [32]. Disease has had a major impact on the shrimp farming industry. Since 1981, a succession of new viral pathogens has emerged in Asia and the Americas, causing mass mortalities and threatening the economic sustainability of the industry [148]. Shrimp are arthropods and most shrimp viruses are either related to those previously known to infect insects (e.g., densoviruses, dicistroviruses, baculoviruses, nodaviruses, luteoviruses) or are completely new to science and have been assigned to new taxa (Tab. II).

Several important characteristics are common to shrimp diseases and distinguish them from most viruses of terrestrial or aquatic vertebrates. Firstly, as invertebrates, shrimp lack the key components of adaptive and innate immune response mechanisms (i.e., antibodies, lymphocytes, cytokines, interferon) and, although Toll-like receptors have been identified, there 
Table II. Emerging viral pathogens of marine and freshwater shrimp.

\begin{tabular}{|c|c|c|c|c|c|c|}
\hline Virus & Abbreviation & Genome & $\begin{array}{c}\text { Taxonomic } \\
\text { classification }^{1}\end{array}$ & Year emerged & $\begin{array}{l}\text { Known geographic } \\
\text { distribution }\end{array}$ & OIE listed disease $^{2}$ \\
\hline \multicolumn{7}{|l|}{$D N A$ viruses } \\
\hline Monodon baculovirus & MBV & dsDNA & Baculoviridae & 1977 & Asia-Pacific, Americas, Africa & No \\
\hline Baculoviral midgut gland necrosis virus & BMNV & dsDNA & Baculoviridae & 1971 & Asia, Australia & No \\
\hline White spot syndrome virus & WSSV & dsDNA & $\begin{array}{l}\text { Nimaviridae, } \\
\text { Whispovirus }\end{array}$ & 1992 & $\begin{array}{c}\text { Asia, Middle-East, } \\
\text { Mediterranean, Americas }\end{array}$ & Yes \\
\hline $\begin{array}{l}\text { Infectious hypodermal and } \\
\text { haematopoietic necrosis virus }\end{array}$ & IHHNV & ssDNA & $\begin{array}{l}\text { Parvoviridae, } \\
\text { Densovirus }\end{array}$ & 1981 & $\begin{array}{c}\text { Asia-Pacific, Africa, Madagascar, } \\
\text { Middle-East, Americas }\end{array}$ & Yes \\
\hline Hepatopancreatic parvovirus & HPV & ssDNA & $\begin{array}{l}\text { Parvoviridae, } \\
\text { Densovirus }\end{array}$ & 1983 & $\begin{array}{c}\text { Asia-Pacific, Africa, Madagascar, } \\
\text { Middle-East, Americas }\end{array}$ & No \\
\hline \multicolumn{7}{|l|}{$R N A$ viruses } \\
\hline Yellow head virus & YHV & \multicolumn{2}{|c|}{$\begin{array}{c}(+) \text { ssRNA Nidovirales, Roniviridae, } \\
\text { Okavirus }\end{array}$} & 1990 & East and Southeast Asia, Mexico & Yes \\
\hline Taura syndrome virus & TSV & $(+)$ ssRNA & $\begin{array}{l}\text { Picornavirales, } \\
\text { Dicistroviridae }\end{array}$ & 1992 & $\begin{array}{c}\text { Americas, East and Southeast } \\
\text { Asia }\end{array}$ & Yes \\
\hline Infectious myonecrosis virus & IMNV & $(+)$ ssRNA & Totivirus (unclassified) & 2002 & $\begin{array}{c}\text { Brazil, Indonesia, Thailand, } \\
\text { China }\end{array}$ & Yes \\
\hline Macrobrachium rosenbergii nodavirus & $\mathrm{MrNV}$ & $(+)$ ssRNA & Nodavirus (unclassified) & 1995 & $\begin{array}{c}\text { India, China, Taiwan, Thailand, } \\
\text { Australia, Caribbean }\end{array}$ & Yes \\
\hline Laem-Singh virus & LSNV & $(+)$ dsRNA & $\begin{array}{l}\text { Luteovirus-like } \\
\text { (unclassified) }\end{array}$ & 2003 & South and Southeast Asia & No \\
\hline Mourilyan virus & $\mathrm{MoV}$ & $(-)$ ssRNA & $\begin{array}{l}\text { Bunyavirus-like } \\
\text { (unclassified) }\end{array}$ & 1996 & Australia, Asia & No \\
\hline
\end{tabular}

${ }^{1}$ ICTV, 2009.

2 OIE, 2009. 
is little evidence that they are involved in antiviral immunity [70, 160]. RNA interference (RNAi) does appear to have a role in the antiviral defensive response of shrimp and there is evidence that viral proteins can induce a shortlived protective immunity $[57,118]$. However, as is the case for insects, the response of shrimp to viral infection is poorly understood and the subject of intensive research. The second distinguishing feature is that most of the major pathogenic viruses cause very low level persistent infections that can occur at moderate to very high prevalence in apparently health shrimp populations [16, 51, 108, 133, 145]. Almost all shrimp pathogens are transmitted vertically (but usually not transovarially) and disease is the result of a massive viral amplification that follows exposure to various forms of environment or physiological stress [22, 81, 113, 119]. Stressors can include handling, spawning, poor water quality or abrupt changes in temperature or salinity. Shrimp viruses can also commonly be transmitted horizontally and, once viral loads are high and disease is manifest, horizontal transmission of infection is accompanied by transmission of disease. The third significant characteristic is a logical consequence of the former two in that shrimp commonly can be infected simultaneously or sequentially with multiple viruses [33], or even different strains of the same virus [50]. These characteristics present a very different landscape for the interaction of pathogen and host and significant challenges for diagnosis, detection, pathogen exclusion and the use of prophylactics in health management. Viruses listed by the OIE as causing notifiable diseases of marine and freshwater shrimp are reviewed briefly in this section.

\subsubsection{White spot syndrome}

White spot syndrome first emerged in Fujian Province of China in 1992 [165]. It was soon after reported in Taiwan and Japan and has since become panzootic throughout shrimp farming regions of Asia and the Americas [148]. It is the most devastating disease of farmed shrimp with social and economic impacts over 15 years on a scale that is seldom seen, even for the most important diseases of terrestrial animals. White spot syndrome virus (WSSV) is a large, enveloped, ovaloid DNA virus with a flagellum-like tail and helical nucleocapsid that has been classified as the only member of the new family Nimaviridae, genus Whispovirus [144, 158]. The $\sim 300 \mathrm{kbp}$ viral genome contains at least 181 ORF, most of which encode polypeptides with no detectable homology to other known proteins [142, 159]. Although first emerging in farmed kuruma shrimp (Penaeus japonicus), WSSV has a very broad host range amongst decapod crustaceans (e.g., marine and freshwater shrimp, crabs, lobsters, crayfish, etc.), all of which appear to be susceptible to infection [72]. However, susceptibility to disease varies and some crustacean species have been reported to develop very high viral loads in the absence of clinical signs [162]. All farmed marine (penaeid) shrimp species are highly susceptible to white spot disease, with mass mortalities commonly reaching $80-100 \%$ in ponds within a period of $3-10$ days $[20,77]$. Persistent, low level infections in shrimp and other crustaceans occur commonly, sometimes at levels that are not detectable, even by nested PCR. The amplification of viral loads and onset of disease can be induced by environmental or physiological stress [80, 113], or at ambient temperatures below $30^{\circ} \mathrm{C}[39,143]$.

WSSV was not known prior to its emergence in China and the original source of infection has not been determined. However, the spread of infection throughout most of Asia during the mid-1990s and subsequently to the Americas from 2001 was explosive and was almost certainly the consequence of a prolific international trade in live shrimp and other crustacean seed and broodstock [76]. The susceptibility of all decapods and absence of evidence of replication in other organisms suggests the virus is of crustacean origin but it remains a mystery why a virus with such broad host range and ease of transmission was not long established globally in crustacean populations prior to the advent of aquaculture [148].

\subsubsection{Taura syndrome}

Taura syndrome first emerged in white Pacific shrimp ( $P$. vannamei) farms on the 
Taura River near Guayaquil in Ecuador in 1992, almost simultaneously with the emergence of WSSV in kuruma shrimp in China [43]. The disease spread rapidly throughout most shrimp farming regions of Central and South America [75]. In 1998, it was detected in Taiwan and has now spread throughout much of Asia [140]. Taura syndrome virus (TSV) is a small, naked (+) ssRNA virus that is currently classified as an unassigned species in the family Dicistroviridae, order Picornavirales [21]. The most closely related known viruses include insect viruses in the genus Cripavirus such as cricket paralysis virus and drosophila $C$ virus [21, 87]. Acute, transitional (recovery) and chronic phases of TSV infection have been described [44]. Mortalities in the acute phase can be as high as $95 \%$ but surviving shrimp remain infected and a potential source of virus transmission. The susceptible host range of TSV is far more restricted than that of WSSV but includes most farmed marine shrimp species. However, susceptibility to disease varies and virulence varies for different strains of the virus. Other crustaceans including freshwater shrimp and crabs appear to be resistant to disease but may be potential carriers [61]. Birds and water-boatmen (Trichocorixa reticulata) have been proposed as possible mechanical vectors $[14,36,126]$. The focal origin of the TSV panzootic and absence of evidence of infection prior to the first outbreak suggest that, as for WSSV, penaeid shrimp are not the natural host. The rapid spread of TSV in the Americas and then to Asia has also been attributed to the international trade in live shrimp.

\subsubsection{Yellow head disease}

Yellow head virus (YHV) is the most virulent of shrimp pathogens, commonly causing total crop loss within several days of the first signs of disease in a pond. It first emerged in black tiger shrimp ( $P$. monodon) in Central Thailand in 1990 and has since been reported in most major shrimp farming countries in Asia, including India, Indonesia, Malaysia, the Philippines, Sri Lanka, Vietnam and Taiwan $[17,145]$. There is also a recent unconfirmed report that YHV is present in farmed $P$. vannamei and $P$. stylirostris in Mexico [25]. YHV is an enveloped, rod-shaped $(+)$ ssRNA virus with a helical nucleocapsid and prominent glycoprotein projections on the virion surface [157]. The particle morphology and organisation and expression strategy of the $\sim 26 \mathrm{~kb}$ genome indicate that it is most closely related to vertebrate coronaviruses, toroviruses and arteriviruses, and it has been classified within the order Nidovirales in the family Ronivirus, genus Okavirus [147]. It is now known that YHV is one of a complex of six closely related viruses infecting $P$. monodon shrimp [153]. Gill-associated virus (GAV) is a far less virulent virus that emerged to cause mid-crop mortality syndrome in farmed P. monodon in Australia in 1996 [124]. However, the prevalence of GAV infection in healthy $P$. monodon broodstock and farmed shrimp in Australia has been reported to approach $100 \%$ and, although disease can be transmitted by injection or exposure per os to moribund shrimp, outbreaks in ponds are most likely the result of amplification of viral loads as a consequence of environmental stress. The other four known genotypes in the complex have been detected only in healthy $P$. monodon in Asia and, although they occur at high prevalence in many locations, they are not known to be associated with disease [153]. Many other penaeid and palemonid shrimp species have been shown to be susceptible to experimental infection with YHV or GAV, but yellow-headcomplex viruses are detected rarely in other penaeid shrimp species and $P$. monodon appears to be the natural host [148]. Nevertheless, the very high virulence of YHV for penaeid shrimp does suggest that this genotype may enter ponds via an alternative reservoir host. Homologous genetic recombination is also a feature of the yellow head complex. A recent study has indicated that $\sim 30 \%$ of yellow-head-complex viruses detected in $P$. monodon from across the Asia-Pacific region are recombinants [154]. The prevalence and geographic distribution of these recombinant viruses suggests that aquaculture and the international trade in live shrimp are the source of rapidly increasing viral genetic diversity. 


\subsubsection{Infectious hypodermal and haematopoietic necrosis}

Infectious hypodermal and haematopoietic necrosis was first detected in Hawaii in 1981, causing mass mortalities in blue shrimp (Penaeus stylirostris) farmed in super-intensive raceways [74]. Infectious hypodermal and haematopoietic necrosis virus (IHHNV) is a small, naked, ssDNA virus that has been classified with several insect viruses in the family Parvoviridae, genus Brevidensovirus [21]. Following its initial detection in Hawaii, IHHNV was found to be widely distributed in both P. stylirostris and $P$. vannamei shrimp throughout farming regions of the Americas and in the wild shrimp population of the Gulf of California where some reports suggest that it may have contributed to the collapse of the capture fishery $[96,111]$. Although it does not cause mortalities in $P$. vannamei, IHHNV has been shown to reduce growth by up to $30 \%$ and cause deformities of the rostrum and anterior appendages in a condition called "runt deformity syndrome" [59]. In Asia, IHHNV is endemic and occurs commonly in P. monodon shrimp which appears to be the natural host and in which it does not cause disease and has no impact on growth or fecundity $[18,155]$. Four genotypes of IHHNV have been identified of which two have been shown to be integrated into host genomic DNA and experimental transmission studies suggest they may not be infectious for $P$. monodon or $P$. vannamei shrimp $[65,135,136]$. The other two genotypes can be transmitted horizontally by injection, ingestion or exposure to infected water, or vertically from infected females [73]. Genetic evidence suggests that P. monodon imported from the Philippines were the source of the epizootic in the Americas, indicating that disease emergence has been the consequence of an expanded host range providing opportunities for pathogenicity and a vastly expanded geographic distribution [134].

\subsubsection{Infectious myonecrosis}

Infectious myonecrosis is the most recently emerging of the major viral diseases of marine shrimp. It first appeared in farmed P. vannamei shrimp at Pernambuco in Brazil in 2002 and has subsequently spread throughout coastal regions of north-east Brazil and to Indonesia, Thailand and Hainan Province in China $[4,79,120]$. The original source of infection is unknown but the trans-continental spread has almost certainly been due to the voluminous trade in $P$. vannamei broodstock. Shrimp with the acute form of the disease display various degrees of skeletal muscle necrosis, visible as an opaque, whitish discolouration of the abdomen [137]. Surviving shrimp progress to a chronic phase with persistent low-level mortalities. Infectious myonecrosis virus (IMNV) is a small, naked, icosahedral, dsRNA virus that is most closely related to members of the family Totiviridae, genus Giardiavirus [116]. The only other known members of this family infect yeasts and protozoa. Several farmed marine shrimp species have been reported to be susceptible to infection but disease has only been reported in white Pacific shrimp [137]. The increasingly common practice in parts of Asia of co-cultivation of white Pacific shrimp and black tiger shrimp is likely to present opportunities for adaptation and further spread of the disease.

\subsubsection{White tail disease}

White tail disease is an emerging infection of the giant freshwater shrimp Macrobrachium rosenbergii. It was first reported in 1995 from the island of Guadeloupe and then nearby Martinique in the French West Indies, and has since been reported from China, Taiwan, Thailand, India and Australia [6, 110, 117, 141, 161]. The disease can affect larvae, postlarvae and early juvenile stages, causing up to $100 \%$ mortalities within 5-7 days of the first gross signs which include a white or milky appearance of abdominal muscle [42, 117]. Adults are resistant to the disease but can be persistently infected and transmit the infection vertically. Marine shrimp (Penaeus monodon, $P$. japonicus and $P$. indicus) have been shown to be susceptible to infection but did not develop disease, and artemia and some species of aquatic insects appear to be vectors $[130,131]$. White tail disease is caused by a 
small, naked $(+)$ ssRNA virus that has been named Macrobrachium rosenbergii nodavirus (MrNV). Sequence alignments indicate that it is related to but distinct from nodaviruses of insects (genus Alphanodavirus) and nodaviruses of fish (genus Betanodavirus) [9]. A very small satellite virus (extra small virus, XSV) appears to be universally associated with natural MrNV infections but is not the direct cause of disease [117]. As the native endemic range of Macrobrachium rosenbergii is restricted to south and south-east Asia, the wide geographic distribution of the disease most likely has been due to the movement of stock for aquaculture purposes. Nevertheless, the detection in 2007 of a distinct strain of MrNV in Macrobrachium rosenbergii broodstock captured from the remote Flinders River in western Queensland, Australia [110], where there is a long-standing enforced prohibition on the importation of live crustaceans, suggests that the virus is a natural infection of freshwater shrimp. Penaeus vannamei nodavirus ( $\mathrm{PvNV}$ ) is a distinct but related virus that was detected in 2004 in cultured marine shrimp in Belize displaying the gross signs of white tail disease [138].

\section{IMPACTS OF EMERGING DISEASES OF FISH AND SHRIMP}

\subsection{Economic and social impacts}

The impacts of emerging diseases of aquatic animals have been substantial; all have affected livelihoods locally and many have impacted on regional or national economies. The most devastating economic and social impacts have been in shrimp aquaculture for which it was estimated in 1996 that the global direct and indirect costs of emerging diseases had reached \$US 3 billion annually or $40 \%$ of the total production capacity of the industry $[55,85]$. The most significant production losses have immediately followed the emergence of each of the major pathogens, with ensuing periods of poor productivity and reduced rates of industry expansion during which pathogens have been identified and characterised, diagnosis and detection methods developed, and improved biosecurity measures implemented [10, 148]. In many cases, impacts have continued for many years, particularly for small low-income farmers in developing countries who lack the knowledge, skill and resources to respond effectively. WSSV has been by far the most devastating of the shrimp pathogens. It has been estimated that the impact of WSSV in Asia alone during the 10 years after its emergence in 1992 was \$US 4-6 billion [78]. In the Americas, the emergence of WSSV in 1999-2000 resulted in immediate losses estimated at \$US 1 billion. The combined impacts of TSV and IHHNV on aquaculture and wild shrimp fisheries in the Americas have been estimated at \$US 1.5-3 billion [44, 78]. The consequences of disease emergence for some countries have been so severe that shrimp production has never fully recovered. Beyond the direct effects on production and profitability, disease impacts on the income and food-security of small-holder shrimp farmers and the job security of workers on larger farms and in feed mills and processing plants, with a flow-on effect to the sustaining local communities [148].

The global economic losses in fish aquaculture due to infectious diseases are of a lesser magnitude, but still highly important in several ways and can be crippling for farmers. Not only are many individual animals of greater commercial value (e.g., koi carp) but the disruption of consistent production schedules by companies engaged in intensive aquaculture can result in loss of market share. The emergence of ISAV in Scotland in 1998-1999 is estimated to have cost the industry $\sim$ \$US 35 million and resulted in an ongoing annual loss of \$US 25 million to the industries in Norway and Canada. The estimated cost of the emergence of KHV in Indonesia was in excess of \$US 15 million during the first 3 years [10], with ongoing socioeconomic impacts on low-income, small-holder farmers.

\subsection{Environmental impacts}

Environmental impacts of emerging diseases of aquatic animals have been both direct and indirect. Disease can impact directly on wild populations and the ecosystem by changing 
host abundance and predator/prey populations, reducing genetic diversity and causing local extinctions [7]. The emergence of pilchard herpesvirus in Australasia during the 1990s was one of the most dramatic examples of largescale impact on ecosystems. Commencing in March 1995, mass mortalities occurred in wild pilchard (Sardinops sagax neopilchardus) populations across $5000 \mathrm{~km}$ of the Australian coastline and $500 \mathrm{~km}$ of the coastline of New Zealand [58]. The epizootic subsided in September 1995 but a second more severe wave of mortalities occurred between October 1998 and April 1999 with vast numbers of pilchards washed onto southern Australian beaches and mortality rates in pilchard populations as high as $75 \%$ [151]. The causative agent was identified as a previously unknown fish herpesvirus, but the source of the epidemic has never been identified [52]. Beyond the direct impact on pilchard populations, wider secondary impacts on piscivorous species were observed. Penguins suffered increased mortalities and failed to breed due to food shortage [24]. The contribution of pilchards to the diet of the Australian gannet (Morus serrator) declined from 60\% to $5 \%$ following the mortality event and was compensated by feeding on species with lower calorific value [15]. As pilchards are important prey for seabirds, fish and marine mammals, other secondary impacts were likely. The recent introduction of VHSV to the Great Lakes Basin has also resulted in large-scale mortalities and spread to at least 25 native freshwater fish species with potential for similar broader environmental impacts [1].

Despite their panzoootic distribution in aquaculture systems and wide crustacean host range, direct environmental impacts of shrimp viruses have not been commonly observed. It has been reported that IHHNV impacted on wild P. stylirostris fisheries in the Gulf of Mexico following its introduction in 1987 [96] but rigorous environmental assessments of the impact of this or other shrimp pathogens have not been conducted. Indirect environmental impacts of disease in shrimp aquaculture are more clearly evident. These include the destruction of mangrove habitats due to pond abandonment and relocation to new sites, soil salinisation in inland areas due to avoidance of disease-prone coastal zones, and use of antibiotics, disinfectants and other chemicals to prevent or treat disease in ponds [3, 93, 148]. Difficulties in managing disease in native Asian marine shrimp species have also led to an extraordinary shift in production since 2001 to imported $P$. vannamei for which SPF stock are readily available [13]. The natural habitat of this species is the west coast of Central America but it now accounts for $67.1 \%$ of total farmed shrimp production in Asia [32], representing a massive species translocation for which the impacts on local biodiversity remain uncertain.

\section{FACTORS CONTRIBUTING TO DISEASE EMERGENCE IN AQUATIC ANIMALS}

The increasing rate of emergence of diseases of fish and shrimp has been driven primarily by anthropogenic influences, the most profound of which have been associated with the global expansion of aquaculture. Farming of aquatic animals commonly involves displacement from their natural habitat to an environment that is new and sometimes stressful, the use of feeds that are sometimes live and often unnatural or artificial, and culture in stocking densities that are much higher than occur naturally. This has provided opportunities for exposure to new pathogens and conditions that can compromise defensive responses and facilitate pathogen replication and disease transmission [146, 148]. Most importantly, the growth in aquaculture and increasing international trade in seafood has resulted in the rapid movement of aquatic animals and their products, with associated risks of the trans-boundary movement of pathogens [129]. Other diseases have been spread by natural or unintentional movement of infected hosts or amplified by invasive species, while anthropogenic environmental pressures have caused changes in the severity of several endemic diseases. Better surveillance activities based upon novel and more sensitive tools and their application in new species and geographic areas have also contributed to an apparent expansion of host or geographic range, sometimes dramatically. 


\subsection{Activities related to the global expansion of aquaculture}

Emerging viral diseases of fish or shrimp are usually caused either by (i) viruses that naturally infect the target species but are unobserved or not normally pathogenic in wild or unstressed populations, or (ii) the spill-over of viruses from other species that may not be encountered naturally. Virus infections occur commonly in apparently healthy populations of wild fish and shrimp and, although disease outbreaks may occasionally occur, these often pass undetected and are not essential to sustain the natural cycle of transmission [149]. In shrimp, IHHNV, yellow-head-complex viruses and possibly MrNV appear to be naturally endemic in healthy wild populations and have emerged as significant pathogens only as a consequence of aquaculture practices. In the case of IHHNV, disease emergence has been due to the translocation of the natural host, $P$. monodon, from the Philippines to Hawaii and the Americas for use in aquaculture breeding programs, allowing spill-over into susceptible western hemisphere shrimp species [134]. For viruses in the yellow head complex, the natural prevalence can approach $100 \%$ in some healthy wild P. monodon populations but stressful culture conditions, in combination with yet uncharacterised virulence determinants, appear to trigger disease outbreaks [26, 145, 153]. Similarly, the emerging fish pathogen ISAV is endemic at relatively high prevalence in wild salmonid populations in Norway and Canada but has been associated with disease only in farmed Atlantic salmon. It has been suggested that intensive culture serves to provide concentrations of susceptible animals in which virulent strains of ISAV emerge due to a combination of high mutation rate and increased opportunity for virus replication [63]. Other major emerging pathogens are clearly not naturally endemic in aquaculture species but have spilled-over into both farmed and wild populations as a consequence of the exposure opportunities provided by the rapid growth of a large and diverse industry. WSSV, TSV and IMNV each appear to have been initially introduced to shrimp populations from unidentified sources that could potentially include experimental live or frozen feeds or co-inhabitants of terrestrial pond environments such as insects or aquatic invertebrates. Nevertheless, each of these viruses now occurs commonly as low-level persistent infections in healthy shrimp populations and disease outbreaks are precipitated by environmental stresses associated with aquaculture. In the case of WSSV, aquaculture has also provided opportunities for spread of infection to a very wide range of new wild crustacean hosts in which the virus has now become endemic across a vast coastal area of Asia and the Americas.

Amongst finfish pathogens, the ranaviruses and nodaviruses provide good examples of the emergence of disease due to spill-over from wild reservoirs. Prior to the availability of large populations of susceptible species reared in aquaculture, the betanodaviruses were endemic but undetected among free-ranging populations of marine fish and various ranaviruses were present in a broad range of native species that included fish, amphibians and reptiles. The introduction of these viruses to commercial aquaculture and the ensuing emergence of disease were likely due to the use of open water supplies and wild-caught broodstock.

The intentional or unintentional movement of infected hosts or pathogens by individuals or companies involved in global aquaculture or the ornamental fish trade has also been an important driver of viral disease emergence in aquatic animals [150]. Exotic viruses translocated into new geographic areas have spread to cause major disease outbreaks in populations of both native and cultured species and the trans-boundary movement of aquatic animals continues to be one of the greatest threats to the productivity and profitability of aquaculture worldwide. For finfish, this is exemplified by the spread of IHNV to Europe and Asia via the shipment of contaminated eggs of trout and salmon, the global spread of SVCV and KHV via the ornamental fish trade and the introduction of the pilchard herpesvirus into native populations of pilchards in Australia via baitfish. For shrimp, the prolific international trade in live broodstock has been the major driver of the explosive trans-boundary 
spread of emerging viral pathogens. The rapid spread of WSSV throughout Asia and then to the Americas has been attributed to the movement of live crustaceans [78]. The magnitude of this problem is most clearly exemplified by the mass translocation of many hundreds of thousands of white Pacific shrimp broodstock from the Americas to Asia, accompanied by the introduction of TSV, IMNV and possibly other exotic pathogens [13]. The international trade in frozen commodity shrimp and shrimp products has also been recognised as a potential mechanism of trans-boundary spread of disease [76]. Several reports have indicated the presence of infectious WSSV and YHV in frozen commodity shrimp imported to the USA and Australia [90, 107]. However, it is yet to be established that the trade in infected frozen product has contributed to disease outbreaks in wild or cultivated shrimp [33b].

\subsection{Improved surveillance}

Apparent changes in the prevalence and distribution of viral diseases of fish and shrimp can also be attributed to improved surveillance as a result of the availability of new cell lines for virus isolation and characterization, the development of more sensitive molecular diagnostic methods, enhanced testing activity in natural ecosystems and greatly improved aquatic animal health diagnostic capability in some developing countries. For some viral pathogens, the availability of improved detection and surveillance capabilities has resulted in reports of a greater host or geographic range than previously known; in other cases, diseases in different species or geographic regions have been shown to be due to the same or similar viruses. For fish diseases, this is exemplified by development of the salmon head kidney (SHK) cell line to detect and characterize ISAV in Norway which subsequently led to the identification of potential carriers and the observation that emerging diseases of Atlantic salmon in Canada and Chile were due to isolates of the same virus [82]. Enhanced surveillance activities also resulted in the detection and isolation of VHSV from normal returning adult salmon on the west coast of North America in 1988. While initially appearing as a large geographic range expansion, increased surveillance activities showed that VHSV is naturally endemic in the North Pacific and North Atlantic Oceans among a wide range of marine species [121]. Similarly, investigations in Australia have identified that several viruses that were previously assumed to be exotic, occur commonly in healthy shrimp populations [110]. The increasing number of previously unknown viruses that have been identified through enhanced surveillance of healthy wild fish and shrimp populations illustrates how little is currently known of the aquatic virosphere.

\subsection{Natural movement of carriers}

The emergence of some viral diseases of fish and shrimp has occurred through expansion of the known geographic range via the natural movement of infected hosts, vectors or carriers with subsequent exposure of naive, and often highly susceptible, species. While the mechanism is not known with certainty, it is considered plausible that VHSV was introduced to the Great Lakes Basin of North America via the natural movement of fish up the Saint Lawrence River from the near shore areas of the Atlantic coast of Canada. The initial introduction of the virus into the Great Lakes preceded the emergence of massive epidemics among several species by at least two years. This has given rise to speculation that a single introduction of VHSV resulted in infection of the most susceptible species such as the native muskellunge (Esox masquinongy) or the invasive round gobi (Neogobius melanostomus) which could amplify the virus sufficiently to increase the infection pressure on a broad range of naive species within the larger ecosystem [40].

\subsection{Other anthropogenic factors}

The emergence of viral disease in aquatic systems can also been driven by anthropogenic factors unrelated to aquaculture such as the movement of pathogens or hosts via ballast water in ships, movement of bait by anglers and unintentional movement in other biotic or abiotic vectors. The environmental impacts of 
increasing global population such as increasing loads of pollutants, contaminants and toxins in aquatic habitats also threaten the health and disease-resistance of both native and farmed fish populations. Finally, water diversions, impoundments, cooling water inputs and other water-use conflicts can result in environmental changes that may be detrimental to the health of aquatic species.

\section{FUTURE DISEASE EMERGENCE RISKS}

The increasing global population, increasing demand for seafood and limitations on production from capture fisheries will inevitably lead the continued global expansion of aquaculture with associated risks of disease emergence and spread. Africa, in particular, which currently contributes less than $1.3 \%$ of global aquaculture production [32], offers significant development opportunities for aquaculture but also presents a rich biodiversity that may be the source of emergence of new aquatic animal pathogens. There are also disease emergence risks associated with the increasing diversity of farmed species, the introduction of species into new farming areas and the increasing trend amongst small-holder farmers in some countries towards polyculture or alternate cropping of several fish and crustacean species to improve productivity.

As is the case for terrestrial pathogens, climate change also looms as a likely future driver of disease emergence in aquatic animals. Climate change and variability are likely to bring ecological disturbance on a global scale that will influence the suitability of aquaculture farming sites and has potential to influence the growth rate of pathogens and the host immune response to infection, generate thermal stress that will increase susceptibility to disease, change the distribution of vectors, carriers and reservoirs and the density or distribution of susceptible wild species, and alter the physical habitat and farming practices in ways that affect disease ecology. Nevertheless, there is a growing awareness of the importance of emerging diseases of aquatic animals and it is likely that the risks of future disease emergence will be mitigated somewhat by the development of improved diagnostic methods and surveillance efforts, increased regulatory oversight of aquaculture with greater levels of health inspection for fish, shrimp and their products involved in international trade, and the development of novel vaccines and therapeutics.

\section{REFERENCES}

[1] Abraham D., Greig L., Viral haemorrhagic septicaemia in the Great Lakes region: management and science needs workshop proceedings. Prepared for the International Joint Commission, the Ontario Ministry of Natural Resources and Great Lakes Fishery Commission, ESSA Technologies, Richmond Hill, Ontario, 2008, p. 11.

[2] Ahne W., Bjorklund H.V., Essbauer S., Fijan N., Kurath G., Winton J.R., Spring viremia of carp (SVC), Dis. Aquat. Org. (2002) 52:261-272.

[3] Ali A.M.S., Rice to shrimp: land use land cover changes and soil degradation in Southwestern Bangladesh, Land Use Policy (2006) 23:421-435.

[4] Andrade T.P.D., Redman R.M., Lightner D.V., Evaluation of the preservation of shrimp samples with Davidson's AFA fixative for infectious myonecrosis virus (IMNV) in situ hybridization, Aquaculture (2008) 278:179-183.

[5] Aoki T., Hirono I., Kurokawa K., Fukuda H., Nahary R., Eldar A., et al., Genome sequences of three koi herpesvirus isolates representing the expanding distribution of an emerging disease threatening koi and common carp worldwide, J. Virol. (2007) 81:5058-5065.

[6] Arcier J.M., Herman F., Lightner D.V., Redman R.M., Mari J., Bonami J.R., A viral disease associated with mortalities in hatchery-reared postlarvae of the giant freshwater prawn Macrobrachium rosenbergii, Dis. Aquat. Org. (1999) 38:177-181.

[7] Arthur J.R., Subasinghe R.P., Potential adverse socio-economic and biological impacts of aquatic animal pathogens due to hatchery-based enhancement of inland open-water systems, and possibilities for their minimisation, in: Arthur J.R., Phillips M.J., Subasinghe R.P., Reantaso M.B., MacRae I.H. (Eds.), Primary Aquatic Animal Health Care in Rural, Smallscale, Aquaculture Development FAO Fisheries, Technical Paper, No. 406, 2002, pp. 113-126.

[8] Bloch B., Gravningen K., Larsen J.L., Encephalomyelitis among turbot associated with a picorna-like agent, Dis. Aquat. Org. (1991) 10:65-70.

[9] Bonami J.R., Shi Z., Qian D., Sri Widada J., White tail disease of the giant freshwater prawn, Macrobrachium rosenbergii: separation of the associated 
virions and characterization of $\mathrm{MrNV}$ as a new type of nodavirus, J. Fish Dis. (2005) 28:23-31.

[10] Bondad-Reantaso M.G., Subasinghe R.P., Arthur J.R., Ogawa K., Chinabut S., Adlard R., et al., Disease and health management in Asian aquaculture, Vet. Parasitol. (2005) 132:249-272.

[11] Bootland L.M., Leong J.C., Infectious hematopoietic necrosis virus, in: Woo P.T.K., Bruno D.W. (Eds.), Fish diseases and disorders, Volume 3, Viral, bacterial and fungal infections, CAB International, Oxon, UK, 1999, pp. 57-121.

[12] Breuil G., Bonami J.R., Pepin J.F., Pichot Y., Viral infection (picorna-like virus) associated with mass mortalities in hatchery-reared sea bass (Dicentrarchus labrax) larvae and juveniles, Aquaculture (1991) 97:109-116.

[13] Briggs M., Funge-Smith S., Subasinghe R., Phillips M., Introductions and movement of Penaeus vannamei and Penaeus stylirostris in Asia and the Pacific, RAP publication 2004/10, FAO Regional Office for Asia and the Pacific, Bangkok, 2004.

[14] Brock J.A., Gose R., Lightner D.V., Hasson K., An overview on Taura syndrome, an important disease of farmed Penaeus vannamei, Swimming through troubled water: Proceedings of the Special Session on Shrimp Farming, Aquaculture '95, World Aquaculture Society, Baton Rouge, 1995, pp. 84-94.

[15] Bunce A., Norman F.I., Changes in the diet of the Australasian gannet (Morus serrator) in response to the 1998 mortality of pilchards (Sardinops sagax), Mar. Freshw. Res. (2000) 51:349-353.

[16] Chakraborty A., Otta S.K., Kumar B.J.S., Hossain M.S., Karunasagar I., Venugopal M.N., Karunasagar I., Prevalence of white spot syndrome virus in wild crustaceans along the coast of India, Curr. Sci. (2002) 82:1392-1397.

[17] Chantanachookin C., Boonyaratpalin S., Kasornchandra J., Direkbusarakom S., Ekpanithanpong U., Supamataya K., et al., Histology and ultrastructure reveal a new granulosis-like virus in Penaeus monodon affected by yellow-head disease, Dis. Aquat. Org. (1993) 17:145-157.

[18] Chayaburakul K., Lightner D.V., Sriurairattana S., Nelson K.T., Withyachumnarnkul B., Different responses to infectious hypodermal and hematopoietic necrosis virus (IHHNV) in Penaeus monodon and P. vannamei, Dis. Aquat. Org. (2005) 67:191-200.

[19] Chinchar V.G., Hyatt A., Miyazaki T., Williams T., Family Iridoviridae: poor viral relations no longer, Curr. Top. Microbiol. Immunol. (2009) 328:123-170.

[20] Chou H.Y., Huang C.Y., Wang C.H., Chiang H.C., Lo C.F., Pathogenicity of a baculovirus infection causing white spot syndrome in cultured penaeid shrimp in Taiwan, Dis. Aquat. Org. (1995) 23 165-173.

[21] Christian P., Carstens E., Domier L., Johnson J., Johnson K., Nakashima N., et al., Family Dicistroviridae, in: Fauquet C.M., Mayo M.A., Maniloff J., Desselberger U., Ball L.A. (Eds.), Virus Taxonomy, VIIIth Report of the International Committee on Taxonomy of Viruses, Elsevier, Academic Press, Amsterdam, 2005, pp. 783-788.

[22] Cowley J.A., Hall M.R., Cadogan L.C., Spann K.M., Walker P.J., Vertical transmission of gill-associated virus (GAV) in the black tiger prawn Penaeus monodon, Dis. Aquat. Org. (2002) 50:95-104.

[23] Dalla Valle L., Negrisolo E., Patarnello P., Zanella L., Maltese C., Bovo G., Colombo L., Sequence comparison and phylogenetic analysis of fish nodaviruses based on the coat protein gene, Arch. Virol. (2001) 146:1125-1137.

[24] Dann P., Norman F.I., Cullen J.M., Neira F.J., Chiaradia A., Mortality and breeding failure of little penguins, Eudyptula minor, in Victoria, 1995-96, following a widespread mortality of pilchard, Sardinops sagax, Mar. Freshw. Res. (2000) 51:355-362.

[25] De la Rosa-Velez J., Cedano-Thomas Y., Cid-Becerra J., Mendez-Payan J.C., Vega-Perez C., Zambrano-Garcia J., Bonami J.R., Presumptive detection of yellow head virus by reverse transcriptasepolymerase chain reaction and dot-blot hybridization in Litopenaeus vannamei and L. stylirostris cultured on the Northwest coast of Mexico, J. Fish Dis. (2006) 29:717-726.

[26] De la Vega E., Degnan B.M., Hall M.R., Cowley J.A., Wilson K.J., Quantitative real-time RT-PCR demonstrates that handling stress can lead to rapid increases of gill-associated virus (GAV) infection levels in Penaeus monodon, Dis. Aquat. Org. (2004) 59:195-203.

[27] Do J.W., Moon C.H., Kim H.J., Ko M.S., Kim S.B., Son J.H., et al., Complete genomic DNA sequence of rock bream iridovirus, Virology (2004) 325:351-363.

[28] Elsayed E., Faisal M., Thomas M., Whelan G., Batts W., Winton J., Isolation of viral haemorrhagic septicaemia virus from muskellunge, Esox masquinongy (Mitchill), in Lake St Clair, Michigan, USA reveals a new sublineage of the North American genotype, J. Fish Dis. (2006) 29:611-619.

[29] Enzmann P.J., Kurath G., Fichtner D., Bergmann S.M., Infectious hematopoietic necrosis virus: monophyletic origin of European isolates from North American genogroup M, Dis. Aquat. Org. (2005) 66:187-195.

[30] Erickson C.L., An artificial landscape-scale fishery in the Bolivian Amazon, Nature (2000) 408:190-193. 
[31] FAO, State of World Fisheries and Aquaculture (SOFIA), Food and Agricultural Organisation of the United Nations, Rome, 2008.

[32] FAO, Fishstat Plus, Food and Agricultural Organisation of the United Nations, Rome, 2009.

[33] Flegel T.W., Nielsen L., Thamavit V., Kongtim S., Pasharawipas T., Presence of multiple viruses in non-diseased, cultivated shrimp at harvest, Aquaculture (2004) 240:55-68.

[33b] Flegel T.W., Review of disease transmission risks from prawn products exported for human consumption, Aquaculture (2009) 209:179-189.

[34] Frerichs G.N., Rodger H.D., Peric Z., Cell culture isolation of piscine neuropathy nodavirus from juvenile sea bass, Dicentrarchus labrax, J. Gen. Virol. (1996) 77:2067-2071.

[35] Gagne N., MacKinnon A.M., Boston L., Souter B., Cook-Versloot M., Griffiths S., Olivier G., Isolation of viral haemorrhagic septicaemia virus from mummichog, stickleback, striped bass and brown trout in eastern Canada, J. Fish Dis. (2007) 30:213-223.

[36] Garza J.R., Hasson K.W., Poulos B.T., Redman R.M., White B.L., Lightner R.V., Demonstration of infectious Taura syndrome virus in the feces of seagulls collected during an epizootic in Texas, J. Aquat. Anim. Health (1997) 9:156-159.

[37] Gilad O., Yun S., Adkison M.A., Way K., Willits N.H., Bercovier H., Hedrick R.P., Molecular comparison of isolates of an emerging fish pathogen, koi herpesvirus, and the effect of water temperature on mortality of experimentally infected koi, J. Gen. Virol. (2003) 84:2661-2668.

[38] Glazebrook J.S., Heasman M.P., Debeer S.W., Picorna-like viral particles associated with mass mortalities in larval barramundi, Lates calcarifer Bloch, J. Fish Dis. (1990) 13:245-249.

[39] Granja C.B., Vidal O.M., Parra G., Salazar M., Hyperthermia reduces viral load of white spot syndrome virus in Penaeus vannamei, Dis. Aquat. Org. (2006) 68:175-180.

[40] Groocock G.H., Getchell R.G., Wooster G.A., Britt K.L., Batts W.N., Winton J.R., et al., Detection of viral hemorrhagic septicemia in round gobies in New York State (USA) waters of Lake Ontario and the St. Lawrence River, Dis. Aquat. Org. (2007) 76:187-192.

[41] Haenen O.L.M., Way K., Bergmann S.M., Ariel E., The emergence of koi herpesvirus and its significance to European aquaculture, Bull. Eur. Assoc. Fish Pathol. (2004) 24:293-307.

[42] Hameed A.S.S., Yoganandhan K., Widada J.S., Bonami J.R., Experimental transmission and tissue tropism of Macrobrachium rosenbergii nodavirus (MrNV) and its associated extra small virus (XSV), Dis. Aquat. Org. (2004) 62:191-196.

[43] Hasson K.W., Lightner D.V., Poulos B.T., Redman R.M., White B.L., Brock J.A., Bonami J.R., Taura syndrome in Penaeus vannamei - Demonstration of a viral etiology, Dis. Aquat. Org. (1995) 23:115-126.

[44] Hasson K.W., Lightner D.V., Mohney L.L., Redman R.M., Poulos B.T., White B.M., Taura syndrome virus (TSV) lesion development and the disease cycle in the Pacific white shrimp Penaeus vannamei, Dis. Aquat. Org. (1999) 36:81-93.

[45] He J.G., Wang S.P., Zeng K., Huang Z.J., Chan S.-M., Systemic disease caused by an iridovirus-like agent in cultured mandarinfish, Sinaperca chuatsi (Basilewshy), in China, J. Fish Dis. (2000) 23:219222.

[46] He J.G., Deng M., Weng S.P., Li Z., Zhou S.Y., Long Q.X., et al., Complete genome analysis of the mandarin fish infectious spleen and kidney necrosis iridovirus, Virology (2001) 291:126-139.

[47] Hedrick R.P., Gilad O., Yun S., Spangenberg J.V., Marty G.D., Nordhausen R.W., et al., A herpesvirus associated with mass mortality of juvenile and adult koi, a strain of common carp, J. Aquat. Anim. Health (2000) 12:44-57.

[48] Hedrick R.P., Batts W.N., Yun S., Traxler G.S., Kaufman J., Winton J.R., Host and geographic range extensions of the North American strain of viral hemorrhagic septicemia virus, Dis. Aquat. Org. (2003) 55:211-220.

[49] Higginbothan J., Piscinae: artificial fishponds in Roman Italy, University of North Carolina Press, Chapel Hill, 1997.

[50] Hoa T., Hodgson R., Oanh D., Phuong N., Preston N., Walker P., Genotypic variations in tandem repeat DNA segments between ribonucleotide reductase subunit genes of white spot syndrome virus (WSSV) isolates from Vietnam, in: Walker P., Lester R., Reantaso M. (Eds.), Diseases in Asian Aquaculture, Asian Fisheries Society, Manila, 2005, pp. 395-403.

[51] Hsu H.C., Lo C.F., Lin S.C., Liu K.F., Peng S.E., Chang Y.S., et al., Studies on effective PCR screening strategies for white spot syndrome virus (WSSV) detection in Penaeus monodon brooders, Dis. Aquat. Org. (1999) 39:13-19.

[52] Hyatt A.D., Hine P.M., Jones J.B., Whittington R.J., Kearns C., Wise T.G., et al., Epizootic mortality in the pilchard Sardinops sagax neopilchardus in Australia and New Zealand in 1995. 2. Identification of a herpesvirus within the gill epithelium, Dis. Aquat. Org. (1997) 28:17-29. 
[53] Hyatt A.D., Gould A.R., Zupanovic Z., Cunningham A.A., Hengstberger S., Whittington R.J., et al., Comparative studies of piscine and amphibian iridoviruses, Arch. Virol. (2000) 145:301-331.

[54] Inouye K., Yamano K., Maeno Y., Nakajima K., Matsuoka M., Wada Y., Sorimachi M., Iridovirus infection of cultured red sea bream, Pagrus major, Fish Pathol. (1992) 27:19-27.

[55] Israngkura A., Sae-Hae S., A review of economic impacts of aquatic animal disease, in: Arthur J.R., Phillips M.J., Subasinghe R.P., Reantaso M.B., McCrae I.H. (Eds.), Primary Aquatic Animal Health Care in Rural, Small-scale Aquaculture Development, Technical Proceedings of the Asia Regional Scoping Workshop. FAO Fisheries Technical Paper 406, FAO, Rome, 2002, pp. 55-61.

[56] Isshiki T., Nishizawa T., Kobayashi T., Nagano T., Miyazaki T., An outbreak of VHSV (viral hemorrhagic septicemia virus) infection in farmed Japanese flounder Paralichthys olivaceus in Japan, Dis. Aquat. Org. (2001) 47:87-99.

[57] Johnson K.N., van Hulten M.C.W., Barnes A.C., "Vaccination" of shrimp against viral pathogens: phenomenology and underlying mechanisms, Vaccine (2008) 26:4885-4892.

[58] Jones J.B., Hyatt A.D., Hine P.M., Whittington R.J., Griffin D.A., Bax N.J., Australasian pilchard mortalities, World J. Microbiol. Biotechnol. (1997) 13:383-392.

[59] Kalagayan G., Godin D., Kanna R., Hagino G., Sweeney J., Wyban J., Brock J., IHHN virus as an etiological factor in runt-deformity-syndrome of juvenile Penaeus vannamei cultured in Hawaii, J. World Aquac. Soc. (1991) 22:235-243.

[60] Kawakami H., Nakajima K., Cultured fish species affected by red sea bream iridoviral disease from 1996 to 2000, Fish Pathol. (2002) 37:45-47.

[61] Kiatpathomchai W., Jaroenram W., Arunrut N., Gangnonngiw W., Boonyawiwat V., Sithigorngul P., Experimental infections reveal that common Thai crustaceans are potential carriers for spread of exotic Taura syndrome virus, Dis. Aquat. Organ. (2008) 79:183-190.

[62] Kibenge F.S.B., Munir K., Kibenge M.J.T., Moneke T.J., Moneke E., Infectious salmon anaemia virus: causative agent, pathogenesis and immunity, Anim. Health Res. Rev. (2004) 5:65-78.

[63] Kibenge F.S.B., Godoy M.G., Wang Y.W., Kibenge M.J.T., Gherardelli V., Mansilla S., et al., Infectious salmon anaemia virus (ISAV) isolated from the ISA disease outbreaks in Chile diverged from ISAV isolates from Norway around 1996 and was disseminated around 2005, based on surface glycoprotein gene sequences, Virol. J. (2009) 6:88.
[64] Kim W.S., Oh M.J., Nishizawa T., Park J.W., Kurath G., Yoshimizu M., Genotyping of Korean isolates of infectious hematopoietic necrosis virus (IHNV) based on the glycoprotein gene, Arch. Virol. (2007) 152:2119-2124.

[65] Krabsetsve K., Cullen B.R., Owens L., Rediscovery of the Australian strain of infectious hypodermal and haematopoietic necrosis virus, Dis. Aquat. Org. (2004) 61:153-158.

[66] Kurath G., Garver K.A., Troyer R.M., Emmenegger E.J., Einer-Jensen K., Anderson E.D., Phylogeography of infectious haematopoietic necrosis virus in North America, J. Gen. Virol. (2003) 84:803-814.

[67] Kurath G., Winton J., Fish rhabdoviruses, in: Mahy B.W.J., van Regenmortel M.H.V. (Eds.), Encyclopedia of Virology, Elsevier, Oxford, 2008, pp. 221-227.

[68] Kurita J., Yuasa K., Ito T., Sano M., Hedrick R.P., Engelsma M.Y., et al., Molecular epidemiology of koi herpesvirus, Fish Pathol. (2009) 44:59-66.

[69] Kurita J.K., Nakajima I.H., Aoki T., Complete genome sequencing of red sea bream iridovirus (RSIV), Fish. Sci. (2002) 68:1113-1115.

[70] Labreuche Y., O'Leary N.A., de la Vega E., Veloso A., Gross P.S., Chapman R.W., et al., Lack of evidence for Litopenaeus vannamei Toll receptor (1Toll) involvement in activation of sequence-independent antiviral immunity in shrimp, Dev. Comp. Immunol. (2009) 33:806-810.

[71] Langdon J.S., Humphrey J.D., Epizootic hematopoietic necrosis, a new viral disease in redfin perch, Perca fluviatilis L, in Australia, J. Fish Dis. (1987) 10:289-297.

[72] Leu J.H., Yang F., Zhang X., Xu X., Kou G.H., Lo C.F., Whispovirus, Curr. Top. Microbiol. Immunol. (2009) 328:197-277.

[73] Lightner D.V., Redman R.M., Bell T.A., Infectious hypodermal and hematopoietic necrosis, a newly recognized virus disease of penaeid shrimp, J. Invertebr. Pathol. (1983) 42:62-70.

[74] Lightner D.V., Redman R.M., Bell T.A., Brock J.A., Detection of IHHN virus in P. stylirostris and $P$. vannamei imported into Hawaii, J. World Mariculture Society (1983) 14:212-225.

[75] Lightner D.V., Epizootiology, distribution and the impact on international trade of two penaeid shrimp viruses in the Americas, Rev. Sci. Tech. Off. Int. Epizoot. (1996) 15:579-601.

[76] Lightner D.V., Redman R.M., Poulos B.T., Nunan L.M., Mari J.L., Hasson K.W., Risk of spread of penaeid shrimp viruses in the Americas by the international movement of live and frozen shrimp, Rev. Sci. Tech. Off. Int. Epizoot. (1997) 16:146-160. 
[77] Lightner D.V., Hasson K.W., White B.L., Redman R.M., Experimental infection of western hemisphere penaeid shrimp with Asian white spot syndrome virus and Asian yellow head virus, J. Aquat. Anim. Health (1998) 10:271-281.

[78] Lightner D.V., The penaeid shrimp viral pandemics due to IHHNV, WSSV, TSV and YHV: history in the Americas and current status, Proceedings of the 32nd Joint UJNR Aquaculture Panel Symposium, Davis and Santa Barbara, California, USA, 2003, pp. $17-20$.

[79] Lightner D.V., Pantoja C.R., Poulos B.T., Tang K.F.J., Redman R.M., Andrade T.P.D., Bonami J.R., Infectious myonecrosis: a new disease in Pacific white shrimp, Global Aquaculture Advocate (2004) 7:85.

[80] Liu B., Yu Z.M., Song X.X., Guan Y.Q., Jian X.F., He J.F., The effect of acute salinity change on white spot syndrome (WSS) outbreaks in Fenneropenaeus chinensis, Aquaculture (2006) 253: 163-170.

[81] Lotz J.M., Anton L.S., Soto M.A., Effect of chronic Taura syndrome virus infection on salinity tolerance of Litopenaeus vannamei, Dis. Aquat. Organ. (2005) 65:75-78.

[82] Lovely J.E., Dannevig B.H., Falk K., Hutchin L., MacKinnon A.M., Melville K.J., et al., First identification of infectious salmon anaemia virus in North America with haemorrhagic kidney syndrome, Dis. Aquat. Organ. (1999) 35:145-148.

[83] Lu L., Zhou S.Y., Chen C., Weng S.P., Chan S.-M., He J.G., Complete genome sequence analysis of an iridovirus isolated from the orange-spotted grouper, Epinephelus coioides, Virology (2005) 339:81-100.

[84] Lumsden J.S., Morrison B., Yason C., Russell S., Young K., Yazdanpanah A., et al., Mortality event in freshwater drum Aplodinotus grunniens from Lake Ontario, Canada, associated with viral haemorrhagic septicemia virus, Type IV, Dis. Aquat. Organ. (2007) 76:99-111.

[85] Lundin C.G., Global attempts to address shrimp disease, Report of the Land, Water and Natural Habitats Division, Environment Department, The World Bank, Washington DC, 1995.

[86] Mao J.H., Hedrick R.P., Chinchar V.G., Molecular characterization, sequence analysis, and taxonomic position of newly isolated fish iridoviruses, Virology (1997) 229:212-220.

[87] Mari J., Poulos B.T., Lightner D.V., Bonami J.R., Shrimp Taura syndrome virus: genomic characterization and similarity with members of the genus Cricket paralysis-like viruses, J. Gen. Virol. (2002) 83:915-926.
[88] Markussen T., Jonassen C.M., Numanovic S., Braaen S., Hjortaas M., Nilsen H., Mjaaland S., Evolutionary mechanisms involved in the virulence of infectious salmon anaemia virus (ISAV), a piscine orthomyxovirus, Virology (2008) 374:515-527.

[89] Matsuoka S., Inouye K., Nakajima K., Cultured fish species affected by red sea bream iridoviral disease from 1991 to 1995 , Fish Pathol. (1996) 31:233-234.

[90] McColl K., Slater J., Jeyasekaran G., Hyatt A.D., Crane M.S., Detection of white spot syndrome virus and yellow head virus in prawns imported into Australia, Aust. Vet. J. (2004) 82:69-74

[91] Meyers T.R., Winton J.R., Viral hemorrhagic septicemia virus in North America, Annu. Rev. Fish Dis. (1995) 5:3-24.

[92] Miller O., Fuller F.J., Gebreyes W.A., Lewbart G.A., Shchelkunov I.S., Shivappa R.B., et al., Phylogenetic analysis of spring virema of carp virus reveals distinct subgroups with common origins for recent isolates in North America and the UK, Dis. Aquat. Org. (2007) 76:193-204.

[93] Miller P., Flaherty M., Szuster B., Inland shrimp farming in Thailand, Aquaculture Asia (1999) 4: 27-32.

[94] Miyata M., Matsuno K., Jung S.J., Danayadol Y., Miyazaki T., Genetic similarity of iridoviruses from Japan and Thailand, J. Fish Dis. (1997) 20:127-134.

[95] Mjaaland S., Rimstad E., Cunningham C.O., Molecular diagnosis of infectious salmon anaemia, in: Cunningham C.O. (Ed.), Molecular diagnosis of salmonid diseases, Kluwer Academic Publishers, Dordrecht, The Netherlands, 2002, pp. 1-22.

[96] Morales-Covarrubias M.S., Nunan L.M., Lightner D.V., Mota-Urbina J.C., Garza-Aguirre M.C., Chavez-Snachez M.C., Prevalence of IHHNV in wild broodstock of Penaeus stylirostris from the upper Gulf of California, Mexico, J. Aquat. Anim. Health (1999) 11:296-301.

[97] Mori K., Nakai T., Nagahara M., Muroga K., Mekuchi T., Kanno T., A viral disease in hatcheryreared larvae and juveniles of redspotted grouper, Fish Pathol. (1991) 26:209-210.

[98] Mori K.I., Nakai T., Muroga K., Arimoto M., Mushiake K., Furusawa I., Properties of a new virus belonging to Nodaviridae found in larval striped jack (Pseudocaranx dentex) with nervous necrosis, Virology (1992) 187:368-371.

[99] Mortensen H.F., Heuer O.E., Lorenzen N., Otte L., Olesen N.J., Isolation of viral haemorrhagic septicaemia virus (VHSV) from wild marine fish species in the Baltic Sea, Kattegat, Skagerrak and the North Sea, Virus Res. (1999) 63:95-106. 
[100] Munday B.L., Langdon J.S., Hyatt A., Humphrey J.D., Mass mortality associated with a viral-induced vacuolating encephalopathy and retinopathy of larval and juvenile barramundi, Lates calcarifer Bloch, Aquaculture (1992) 103:197-211.

[101] Munday B.L., Kwang J., Moody N., Betanodavirus infections in teleost fish: a review, J. Fish Dis. (2002) 25:127-142.

[102] Naish K.A., Taylor J.E., Levin P.S., Quinn T.P., Winton J.R., Huppert D., Hilborn R., An evaluation of the effects of conservation and fishery enhancement hatcheries on wild populations of salmon, Adv. Mar. Biol. (2008) 53:61-194.

[103] Nakajima K., Maeno Y., Yokoyama K., Kaji C., Manabe S., Antigen analysis of red sea bream iridovirus and comparison with other fish iridoviruses, Fish Pathol. (1998) 33:73-78.

[104] Nishizawa T., Mori K.I., Furuhashi M., Nakai T., Furusawa I., Muroga K., Comparison of coat protein genes of 5 fish nodaviruses, the causative agents of viral nervous necrosis in marine fish, J. Gen. Virol. (1995) 76:1563-1569.

[105] Nishizawa T., Furuhashi M., Nagai T., Nakai T., Muroga K., Genomic classification of fish nodaviruses by molecular phylogenetic analysis of the coat protein gene, Appl. Environ. Microbiol. (1997) 63:16331636.

[106] Nishizawa T., Kinoshita S., Kim W.S., Higashi S., Yoshimizu M., Nucleotide diversity of Japanese isolates of infectious hematopoietic necrosis virus (IHNV) based on the glycoprotein gene, Dis. Aquat. Org. (2006) 71:267-272.

[107] Nunan L.M., Poulos B.T., Lightner D.V., The detection of white spot syndrome virus (WSSV) and yellow head virus (YHV) in imported commodity shrimp, Aquaculture (1998) 160:19-30.

[108] Nunan L.M., Arce S.M., Staha R.J., Lightner D.V., Prevalence of infectious hypodermal and hematopoietic necrosis virus (IHHNV) and white spot syndrome virus (WSSV) in Litopenaeus vannamei in the Pacific Ocean off the coast of Panama, J. World Aquac. Soc. (2001) 32:330-334.

[109] Nylund A., Hovland T., Watanabe K., Endresen C., Presence of infectious salmon anemia virus (ISAV) in tissues of Atlantic salmon, Salmo salar L, collected during 3 separate outbreaks of the disease, J. Fish Dis. (1995) 18:135-145.

[110] Owens L., La Fauce K., Juntunen K., Hayakijkosol O., Zeng C., Macrobrachium rosenbergii nodavirus disease (white tail disease) in Australia, Dis. Aquat. Org. (2009) 85:175-180.

[111] Pantoja C.R., Lightner D.V., Holtschmit K.H., Prevalence and geographic distribution of infectious hypodermal and hematopoietic necrosis virus (IHHNV) in wild blue shrimp Penaeus stylirostris from the Gulf of California, Mexico, J. Aquat. Anim. Health (1999) 11:23-34.

[112] Penaranda M.M.D., Purcel M.K., Kurath G., Differential virulence mechanisms of infectious hematopoietic necrosis virus in rainbow trout (Oncorhynchus mykiss) include host entry and virus replication kinetics, J. Gen. Virol. (2009) 90:2172-2182.

[113] Peng S.E., Lo C.F., Liu K.F., Kou G.H., The transition from pre-patent to patent infection of white spot syndrome virus (WSSV) in Penaeus monodon triggered by pereiopod excision, Fish Pathol. (1998) 33:395-400.

[114] Picco A.M., Collins J.P., Amphibian commerce as a likely source of pathogen pollution, Conserv. Biol. (2008) 22:1582-1589.

[115] Plarre H., Devold M., Snow M., Nylund A., Prevalence of infectious salmon anaemia virus (ISAV) in wild salmonids in western Norway, Dis. Aquat. Org. (2005) 66:71-79.

[116] Poulos B.T., Tang K.F., Pantoja C.R., Bonami J.R., Lightner D.V., Purification and characterization of infectious myonecrosis virus of penaeid shrimp, J. Gen. Virol. (2006) 87:987-996.

[117] Qian D., Shi Z., Zhang S., Cao Z., Liu W., Li L., et al., Extra small virus-like particles (XSV) and nodavirus associated with whitish muscle disease in the giant freshwater prawn, Macrobrachium rosenbergii, J. Fish Dis. (2003) 26:521-527.

[118] Robalino J., Bartlett T.C., Chapman R.W., Gross P.S., Browdy C.L., Warr G.W., Double-stranded RNA and antiviral immunity in marine shrimp: inducible host mechanisms and evidence for the evolution of viral counter-responses, Dev. Comp. Immunol. (2007) 31:539-547.

[119] Sanchez-Martinez J.G., Aguirre-Guzman G., Mejia-Ruiz H., White spot syndrome virus in cultured shrimp: a review, Aquac. Res. (2007) 38:1339-1354.

[120] Senapin S., Phewsaiya K., Briggs M., Flegel T.W., Outbreaks of infectious myonecrosis virus (IMNV) in Indonesia confirmed by genome sequencing and use of an alternative RT-PCR detection method, Aquaculture (2007) 266:32-38.

[121] Skall H.F., Olesen N.J., Mellergaard S., Viral haemorrhagic septicaemia virus in marine fish and its implications for fish farming - a review, J. Fish Dis. (2005) 28:509-529.

[122] Skliris G.P., Krondiris J.V., Sideris D.C., Shinn A.P., Starkey W.G., Richards R.H., Phylogenetic and antigenic characterization of new fish nodavirus isolates from Europe and Asia, Virus Res. (2001) 75:59-67. 
[123] Smail D.A., Viral haemorrhagic septicaemia, in: Woo P.T.K., Bruno D.W. (Eds.), Fish diseases and disorders, Volume 3: Viral, bacterial and fungal infections, CAB International, Oxon, UK, 1999, pp. 123-147.

[124] Spann K.M., Cowley J.A., Walker P.J., Lester R.J.G., A yellow-head like virus from Penaeus monodon cultured in Australia, Dis. Aquat. Org. (1997) 31:169-179.

[125] St-Hilaire S., Beevers N., Way K., Le Deuff R.M., Martin P., Joiner C., Reactivation of koi herpesvirus infections in common carp Cyprinus carpio, Dis. Aquat. Org. (2005) 67:15-23.

[126] Stentiford G.D., Bonami J.R., Alday-Sanz V., A critical review of susceptibility of crustaceans to Taura syndrome, yellowhead disease and white spot disease and implications of inclusion of these diseases in European legislation, Aquaculture (2009) 291:1-17.

[127] Stone D.M., Ahne W., Denham K.L., Dixon P.F., Liu C.T.Y., Sheppard A.M., et al., Nucleotide sequence analysis of the glycoprotein gene of putative spring viraemia of carp virus and pike fry rhabdovirus isolates reveals four genogroups, Dis. Aquat. Org. (2003) 53:203-210.

[128] Subasinghe R.P., Bondad-Reantaso M.G., Biosecurity in aquaculture: International agreements and instruments, their compliance, prospects, and challenges for developing countries, in: Scarfe A.D., Lee C.S., O'Bryen P.J. (Eds.), Aquaculture biosecurity: prevention, control, and eradication of aquatic animal disease, Blackwell Publishing, 2006, pp. 9-16.

[129] Subasinghe R.P., Bondad-Reantaso M.G., The FAO/NACA Asia regional technical guidelines for the responsible movement of live aquatic animals: lessons learned from their development and implementation, Rev. Sci. Tech. Off. Int. Epizoot. (2008) 27:54-63.

[130] Sudhakaran R., Musthaq S.S., Haribabu P., Mukherjee S.C., Gopal C., Hameed A.S.S., Experimental transmission of Macrobrachium rosenbergii nodavirus (MrNV) and extra small virus (XSV) in three species of marine shrimp (Penaeus indicus, Penaeus japonicus and Penaeus monodon), Aquaculture (2006) 257:136-141.

[131] Sudhakaran R., Haribabu P., Kumar S.R., Sarathi M., Ahmed V.P.I., Babu V.S., et al., Natural aquatic insect carriers of Macrobrachium rosenbergii nodavirus (MrNV) and extra small virus (XSV), Dis. Aquat. Org. (2008) 79:141-145.

[132] Sudthongkong C., Miyata M., Miyazaki T., Viral DNA sequences of genes encoding the ATPase and the major capsid protein of tropical iridovirus isolates which are pathogenic to fishes in Japan, South China Sea and Southeast Asian countries, Arch. Virol. (2002) 147:2089-2109.
[133] Tan Y., Xing Y., Zhang H., Feng Y., Zhou Y., Shi Z.L., Molecular detection of three shrimp viruses and genetic variation of white spot syndrome virus in Hainan Province, China, in 2007, J. Fish Dis. (2009) 32:777-784.

[134] Tang K.F., Lightner D.V., Low sequence variation among isolates of infectious hypodermal and hematopoietic necrosis virus (IHHNV) originating from Hawaii and the Americas, Dis. Aquat. Org. (2002) 49:93-97.

[135] Tang K.F., Poulos B.T., Wang J., Redman R.M., Shih H.H., Lightner D.V., Geographic variations among infectious hypodermal and hematopoietic necrosis virus (IHHNV) isolates and characteristics of their infection, Dis. Aquat. Org. (2003) 53: 91-99.

[136] Tang K.F., Lightner D.V., Infectious hypodermal and hematopoietic necrosis virus (IHHNV)-related sequences in the genome of the black tiger prawn Penaeus monodon from Africa and Australia, Virus Res. (2006) 118:185-191.

[137] Tang K.F.J., Pantoja C.R., Poulos B.T., Redman R.M., Lightnere D.V., In situ hybridization demonstrates that Litopenaeus vannamei, L. stylirostris and Penaeus monodon are susceptible to experimental infection with infectious myonecrosis virus (IMNV), Dis. Aquat. Org. (2005) 63:261-265.

[138] Tang K.F.J., Pantoja C.R., Redman R.M., Lightner D.V., Development of in situ hybridization and RT-PCR assay for the detection of a nodavirus (PvNV) that causes muscle necrosis in Penaeus vannamei, Dis. Aquat. Org. (2007) 75:183-190.

[139] Thiery R., Cozien J., de Boisseson C., KerbartBoscher S., Nevarez L., Genomic classification of new betanodavirus isolates by phylogenetic analysis of the coat protein gene suggests a low host-fish species specificity, J. Gen. Virol. (2004) 85:3079-3087.

[140] Tu C., Huang H.T., Chuang S.H., Hsu J.P., Kuo S.T., Li N.J., et al., Taura syndrome in Pacific white shrimp Penaeus vannamei cultured in Taiwan, Dis. Aquat. Org. (1999) 38:159-161.

[141] Tung C.W., Wang C.S., Chen S.N., Histological and electron microscopic study on Macrobrachium muscle virus (MMV) infection in the giant freshwater prawn, Macrobrachium rosenbergii (de Man), cultured in Taiwan, J. Fish Dis. (1999) 22:319-323.

[142] Van Hulten M.C.W., Witteveldt J., Peters S., Kloosterboer N., Tarchini R., Fiers M., et al., The white spot syndrome virus DNA genome sequence, Virology (2001) 286:7-22.

[143] Vidal O.M., Granja C.B., Aranguren F., Brock J.A., Salazar M., A profound effect of hyperthermia on survival of Litopenaeus vannamei juveniles infected 
with white spot syndrome virus, J. World Aquac. Soc. (2001) 32:364-372.

[144] Vlak J.M., Bonami J.R., Flegel T.W., Kou G.H., Lightner D.V., Lo C.F., et al., Family Nimaviridae, in: Fauquet C.M., Mayo M.A., Maniloff J., Desselberger U., Ball L.A. (Eds.), Virus Taxonomy: VIIIth Report of the International Committee on Taxonomy of Viruses, Elsevier, Academic Press, London, 2005, pp. 187-192.

[145] Walker P.J., Cowley J.A., Spann K.M., Hodgson R.A.J., Hall M.R., Withychumnarnkul B., Yellow head complex viruses: transmission cycles and topographical distribution in the Asia-Pacific region, in: Browdy C.L., Jory D.J. (Eds.), The new wave: Proceedings of the Special Session on Sustainable Shrimp Culture, Aquaculture 2001, World Aquaculture Society, Baton Rouge, 2001, pp. 292-302.

[146] Walker P.J., Disease emergence and food security: global impact of pathogens on sustainable aquaculture production, in: Brown A.G. (Ed.), Fish, Aquaculture and Food Security, The ASTE Crawford Fund, Canberra, 2004, pp. 44-50.

[147] Walker P.J., Bonami J.R., Boonsaeng V., Chang P.S., Cowley J.A., Enjuanes L., et al., Family Roniviridae, in: Fauquet C.M., Mayo M.A., Maniloff J., Desselberger U., Ball L.A. (Eds.), Virus Taxonomy, VIIIth Report of the International Committee on Taxonomy of Viruses, Elsevier, Academic Press, Amsterdam, 2005, pp 975-979.

[148] Walker P.J., Mohan C.V., Viral disease emergence in shrimp aquaculture: origins, impacts and the effectiveness of health management strategies, Rev. Aquac. (2009) 1:125-154.

[149] Ward J.R., Lafferty K.D., The elusive baseline of marine disease: are diseases in ocean ecosystems increasing?, PLOS Biol. (2004) 2:542-547.

[150] Whittington R.J., Chong R., Global trade in ornamental fish from an Australian perspective: the case for revised import risk analysis and management strategies, Prev. Vet. Med. (2007) 81:92-116.

[151] Whittington R.J., Crockford M., Jordan D., Jones B., Herpesvirus that caused epizootic mortality in 1995 and 1998 in pilchard, Sardinops sagax neopilchardus (Steindachner), in Australia is now endemic, J. Fish Dis. (2008) 31:97-105.

[152] Whittington R.J., Becker J.A., Dennis M.M., Iridovirus infections in finfish - critical review with emphasis on ranaviruses, J. Fish Dis. (2010) 33:95-122.

[153] Wijegoonawardane P.K., Cowley J.A., Phan T., Hodgson R.A., Nielsen L., Kiatpathomchai W., Walker P.J., Genetic diversity in the yellow head nidovirus complex, Virology (2008) 380:213-225.
[154] Wijegoonawardane P.K., Sittidilokratna N., Petchampai N., Cowley J.A., Gudkovs N., Walker P.J., Homologous genetic recombination in the yellow head complex of nidoviruses infecting Penaeus monodon shrimp, Virology (2009) 390:79-88.

[155] Withyachumnarnkul B., Chayaburakul K., Supak L.A., Plodpai P., Sritunyalucksana K., Nash G., Low impact of infectious hypodermal and hematopoietic necrosis virus (IHHNV) on growth and reproductive performance of Penaeus monodon, Dis. Aquat. Org. (2006) 69:129-136.

[156] Wolf K., Infectious hematopoietic necrosis, Fish viruses and fish viral diseases, Cornell University Press, Ithaca, New York, 1988.

[157] Wongteerasupaya C., Sriurairatana S., Vickers J.E., Akrajamorn A., Boonsaeng V., Panyim S., et al., Yellow head virus of Penaeus monodon is an RNA virus, Dis. Aquat. Org. (1995) 22:45-50.

[158] Wongteerasupaya C., Vickers J.E., Sriurairatana S., Nash G.L., Akarajamorn A., Boonsaeng V., et al., A non-occluded, systemic baculovirus that occurs in cells of ectodermal and mesodermal origin and causes high mortality in the black tiger prawn Penaeus monodon, Dis. Aquat. Org. (1995) 21:69-77.

[159] Yang F., He J., Lin X.H., Li Q., Pan D., Zhang X.B., Xu X., Complete genome sequence of the shrimp white spot bacilliform virus, J. Virol. (2001) 75:11811-11820.

[160] Yang L.S., Yin Z.X., Liao J.X., Huang X.D., Guo C.J., Weng S.P., et al., A Toll receptor in shrimp, Mol. Immunol. (2007) 44:1999-2008.

[161] Yoganandhan K., Leartvibhas M., Sriwongpuk S., Limsuwan C., White tail disease of the giant freshwater prawn Macrobrachium rosenbergii in Thailand, Dis. Aquat. Org. (2006) 69:255-258.

[162] Yoganandhan K., Hameed A.S., Tolerance to white spot syndrome virus (WSSV) in the freshwater prawn Macrobrachium rosenbergii is associated with low VP28 envelope protein expression, Dis. Aquat. Org. (2007) 73:193-199.

[163] Yoshikoshi K., Inoue K., Viral nervous necrosis in hatchery-reared larvae and juveniles of Japanese parrotfish, Oplegnathus fasciatus (Temminck and Schlegel), J. Fish Dis. (1990) 13:69-77.

[164] Yoshimiza M., Disease problems of salmonid fish in Japan caused by international trade, Rev. Sci. Tech. Off. Int. Epizoot. (1996) 15:533-549.

[165] Zhan W.B., Wang Y.H., Fryer J.L., Yu K.K., Fukuda H., Meng Q.X., White spot syndrome virus infection of cultured shrimp in China, J. Aquat. Anim. Health (1998) 10:405-410. 